University of Nebraska - Lincoln

DigitalCommons@University of Nebraska - Lincoln

Publications, Agencies and Staff of the U.S.

Department of Commerce

U.S. Department of Commerce

$7-2008$

\title{
Eastern temperate North Pacific offshore killer whales (Orcinus orca): Occurrence, movements, and insights into feeding ecology
}

\author{
Marilyn Dahlheim \\ Alisa Schulman-Janiger \\ San Pedro, California \\ Nancy Black \\ Monterey Bay Cetacean Project \\ Richard Ternullo \\ Monterey Bay Cetacean Project \\ Dave Ellifrit \\ Center for Whale Research \\ See next page for additional authors
}

Alaska Fisheries Science Center, National Marine Mammal Laboratory

Follow this and additional works at: https://digitalcommons.unl.edu/usdeptcommercepub

Part of the Environmental Sciences Commons

Dahlheim, Marilyn; Schulman-Janiger, Alisa; Black, Nancy; Ternullo, Richard; Ellifrit, Dave; and Balcomb, Kenneth III, "Eastern temperate North Pacific offshore killer whales (Orcinus orca): Occurrence, movements, and insights into feeding ecology" (2008). Publications, Agencies and Staff of the U.S. Department of Commerce. 169.

https://digitalcommons.unl.edu/usdeptcommercepub/169

This Article is brought to you for free and open access by the U.S. Department of Commerce at DigitalCommons@University of Nebraska - Lincoln. It has been accepted for inclusion in Publications, Agencies and Staff of the U.S. Department of Commerce by an authorized administrator of DigitalCommons@University of Nebraska - Lincoln. 


\section{Authors}

Marilyn Dahlheim, Alisa Schulman-Janiger, Nancy Black, Richard Ternullo, Dave Ellifrit, and Kenneth

Balcomb III 
MARINE MAMMAL SCIENCE, 24(3): 719-729 (July 2008)

(C) 2008 by the Society for Marine Mammalogy

No claim to original US government works

DOI: $10.1111 / j .1748-7692.2008 .00206 . x$

\title{
Eastern temperate North Pacific offshore killer whales (Orcinus orca):
} Occurrence, movements, and insights into feeding ecology

\author{
MariLYN E. DAHLHEIM \\ Alaska Fisheries Science Center, \\ National Marine Mammal Laboratory, \\ 7600 Sand Point Way, Seattle, Washington 98115, U.S.A. \\ E-mail: marilyn.dahlheim@noaa.gov \\ Alisa Schulman-Janiger \\ 2716 Denison Avenue, \\ San Pedro, California 90731, U.S.A. \\ NANCY BLACK \\ RichaRd TERnUlLo \\ Monterey Bay Cetacean Project, \\ P. O. Box 52001, Pacific Grove, \\ California 93950, U.S.A. \\ DAVE ELLIFRIT \\ KenNETH C. BALCOMB III \\ Center for Whale Research, \\ 355 Smuggler's Cove Road, Friday Harbor, \\ California 98250, U.S.A.
}

Beginning in the late 1980s, large groups of previously unidentified killer whales (Orcinus orca) were sighted off the west coast of Vancouver Island and in the Queen Charlotte Islands, British Columbia. Scientists working in this region produced two killer whale photo-identification catalogues that included both transient (mammaleating) whales and 65 individual whales that investigators believed represented a distinct killer whale community (Ford et al. 1992, Heise et al. 1993). It was thought that these killer whales maintained a generally offshore distribution and were provisionally termed "offshores"; a term that has since been used as a population identifier for the eastern temperate North Pacific offshore killer whale population. Then in September 1992, 75 unidentified whales entered the Strait of Juan de Fuca just south and east of Victoria, British Columbia (Walters et al. 1992). Although most of these whales had not been seen before, two were matched to killer whales in the Queen Charlotte photo-identification catalogue (Ford et al. 1992, Heise et al. 1993) and were thus listed as "offshore" killer whales. During a similar time period, other large groups of killer whales, previously unidentified, were also being sighted off Alaska and California (Dahlheim et al. 1997; Nancy Black and Alisa SchulmanJaniger, unpublished data, respectively).

As the number of encounters increased, certain characteristics were consistently observed among "offshore" killer whales (Ford et al. 2000; this study, Fig. 1). 


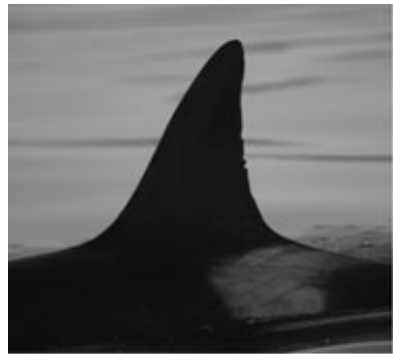

OFFSHORE WHALE

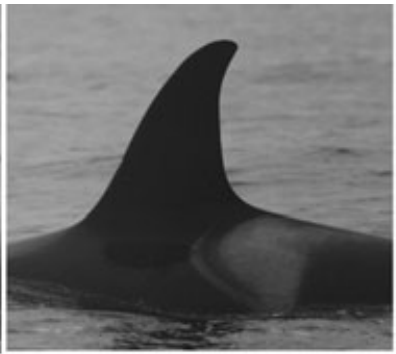

RESIDENT WHALE

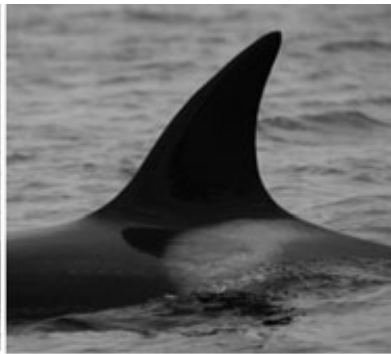

TRANSIENT WHALE

Figure 1. Photographs depicting morphological differences in killer whale ecotypes.

Morphologically, offshore killer whales more closely resembled resident (fish-eating) killer whales than transient killer whales. However, offshore killer whales appeared to be smaller than either the resident or transient ecotype. For example, large offshore males were roughly the size of adolescent males in the resident communities, and less dimorphism was observed between the sexes. In the offshore killer whale ecotype, the tip of the dorsal fin was rounded like those of resident killer whales but more so, being round over the entire tip. Many offshore killer whales had multiple nicks on the trailing edge of the dorsal fin. Their saddle patch shape was similar in size to that of resident killer whales and was usually closed (i.e., no intrusion of black pigmentation into the gray saddle); however, the saddle patch showed more variation than that described for transient killer whales (Baird and Stacey 1988).

When approached by boat, offshore killer whales frequently were more evasive (e.g., erratic and prolonged dive times) than resident or transient killer whales. Group size was typically large, with counts up to 75-100 individuals; this is greater than that reported for transients, but comparable to multi-pod associations of resident killer whales. Distinct differences were found in the acoustic behavior among the three ecotypes (Ford et al. 1992). Furthermore, mtDNA analysis noted a fixed difference between offshore killer whales and the other two eco-types, with offshore killer whales more closely related to resident killer whales than transient killer whales (Hoelzel et al. 1998, 2002). Although the ranges of the three ecotypes occasionally overlapped, offshore killer whales were never observed to intermix with resident or transient killer whales.

Since 1990, the increase in encounters with offshore killer whales has allowed valuable insights into their life history. The purpose of this study was to: (1) identify individual offshore killer whales that occupied Alaska, Washington, Oregon, and California waters; (2) report on the photographic matches of individual whales to determine interchange within and among four main study areas; (3) examine the range of movements undertaken by offshore killer whales; and (4) summarize preliminary observations made during feeding events.

In Alaska, dedicated killer whale studies were conducted by research staff from the Alaska Fisheries Science Center (AFSC), National Marine Mammal Laboratory (NMML), Seattle, Washington. The study areas included western Alaska (to include 


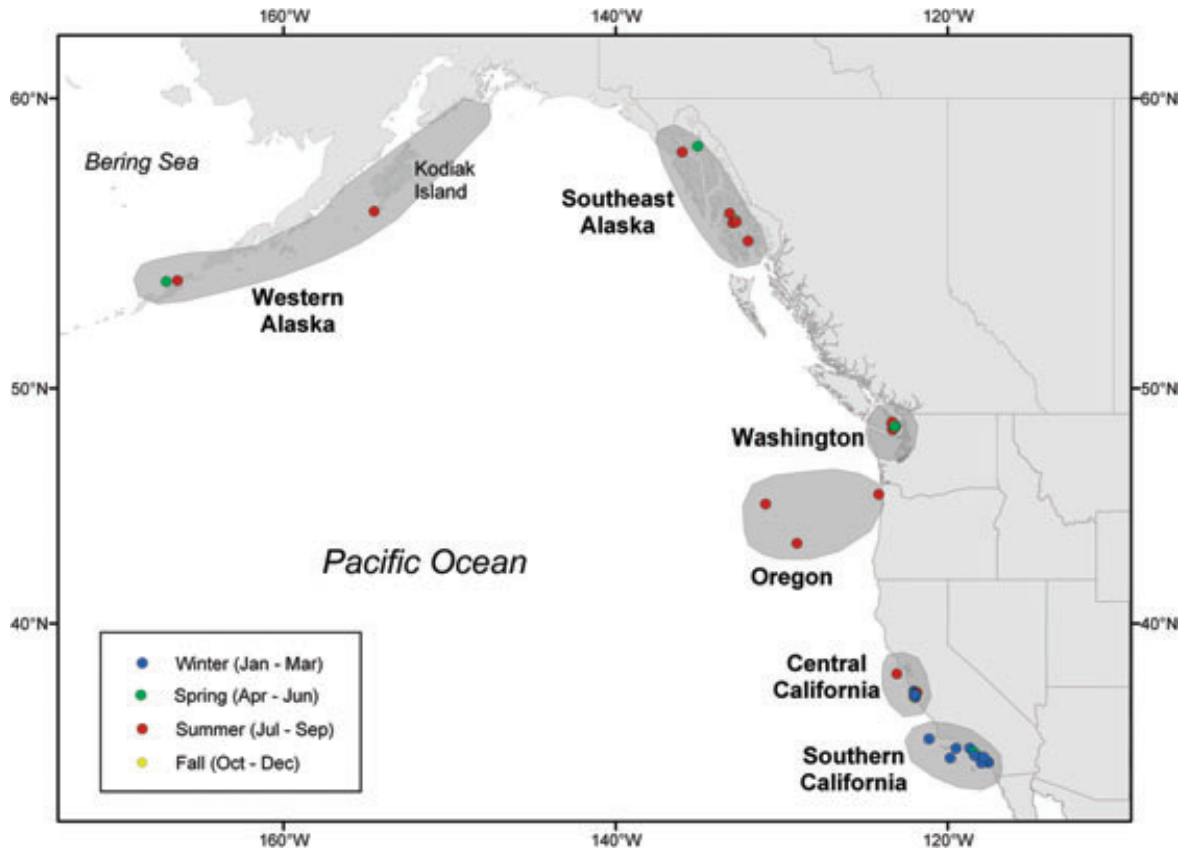

Figure 2. Study areas and encounter locations of offshore killer whales. For California, the eight fall encounters are masked by the high number of encounters that occurred during winter periods. For other study areas, the absence of encounters during different seasons is largely due to the lack of observer effort in that region.

the Kodiak Island area and the southern Bering Sea) and the waters of Southeast Alaska (Fig. 2). Surveys in western Alaska occurred during the summer months (June, July, or August) and were conducted in 1992, 1993, and each year from 2001 to 2007. From 1991 to 2007, surveys in Southeast Alaska occurred two to three times per year spanning spring, summer, and fall seasons (i.e., April/May, June/July, and September, respectively). In Washington State, the Center for Whale Research (CWR) has been conducting dedicated killer whale studies since 1976 throughout waters of Puget Sound and the adjacent inland waters south and east of Vancouver Island, Canada (Fig. 2). In the earlier years, much of CWR's survey effort was conducted during the summer months and was limited in area coverage. However, in the last decade, CWR studies have been conducted year-round and area coverage has been increased. Surveys in the pelagic waters off Oregon were conducted by researchers from the National Marine Fisheries Service on three different occasions: July 1994 (NMML and Southwest Fisheries Science Center (SWFSC), and September 1996 and August 2001 (SWFSC). For central California, dedicated and opportunistic killer whale studies began in 1987 off Monterey Bay with effort approximately equal throughout all seasons. Off southern California opportunistic efforts to study killer whales began in 1984 (Fig. 2).

For each encounter, date, time, location, group size, percentage of whales in the group which photographs were obtained, and behavior were recorded. Individual 
whales were identified based on dorsal fin shape and nicks, and saddle patch shape, size, and markings. Whales with at least two unique features (e.g., nicks on the dorsal fin plus overt saddle markings) were considered well marked and thus listed as distinctive. Only high-quality images that were sharp in definition and had proper lighting were used for analysis. The best photograph of each whale was printed and then compared against the working photographic catalogues compiled for offshore killer whales in the four study areas. Photographic matches within and among areas allowed us to calculate the range of movements traveled by individual offshore killer whales. The total distance traveled was obtained using straight-line calculations derived from the latitude and longitude of each encounter; a method that most likely underestimates the actual distance traveled by the whales. By examining the shortest time interval of an individual offshore killer whale between two locations, a maximum travel time was also calculated.

Despite considerable research effort directed at killer whales along the coasts of California, Oregon, Washington, and Alaska, only 59 sightings of offshore killer whales have been documented during the last 30 years (Fig. 2). Of these, the majority of sightings $(n=40)$ have occurred off California. Despite year-round effort in this area, offshore killer whales are rarely seen between the months of April and August. Offshore killer whales were seen in large groups as follows: Western Alaska (three sightings of 20-60 whales/group), Southeast Alaska (seven sightings of 9-75 whales/group), Washington (six sightings of 40-75 whales/group; however, four of the six sightings reported here represent the same group of whales seen on consecutive days), Oregon (three sightings of 2-16 whales/group), and California (40 sightings of 2-100 whales/group; 30 sightings of which consisted of 20-100 whales/group).

Photographic matches, using only well-marked individuals, resulted in the following: 57 matches between Alaska and Washington, 6 matches between Alaska and Oregon, 81 matches occurred between Alaska and California, 2 matches between Washington and Oregon, 68 matches between Washington and California, and 4 matches between Oregon and California (Fig. 3). Of these, 46 whales were sighted in all three locations (i.e., California, Washington, and Alaska) with one whale seen in all four locations. Photographic matches were also found among the three focused effort locations within Alaska (i.e., Bering Sea, Gulf of Alaska, and Southeast) and between central and southern California. Table 1 depicts the number of well-marked (i.e., distinctive) offshore killer whales identified by location and photographic matches among all locations. Although not every individual offshore killer whale was seen with every other animal, all but two offshore encounters were linked by association (i.e., a Bering Sea encounter and an Oregon encounter). Of particular interest are the matches that have occurred of the two offshore killer whales seen $389 \mathrm{~km}$ off the coast of Oregon in waters depths $>3,000 \mathrm{~m}$. One whale (CA 531) has been seen five times off coastal California, two times off Washington, two times off British Columbia, and one time off Southeast Alaska. The other whale (CA539) has been documented twice off coastal California (see Black et al. 1997). These matches represent the furthest offshore match with any coastal killer whale.

Long-distance movements were frequently undertaken by offshore killer whales. The longest distance traveled was $4,435 \mathrm{~km}$ from Dutch Harbor, Alaska to Dana 


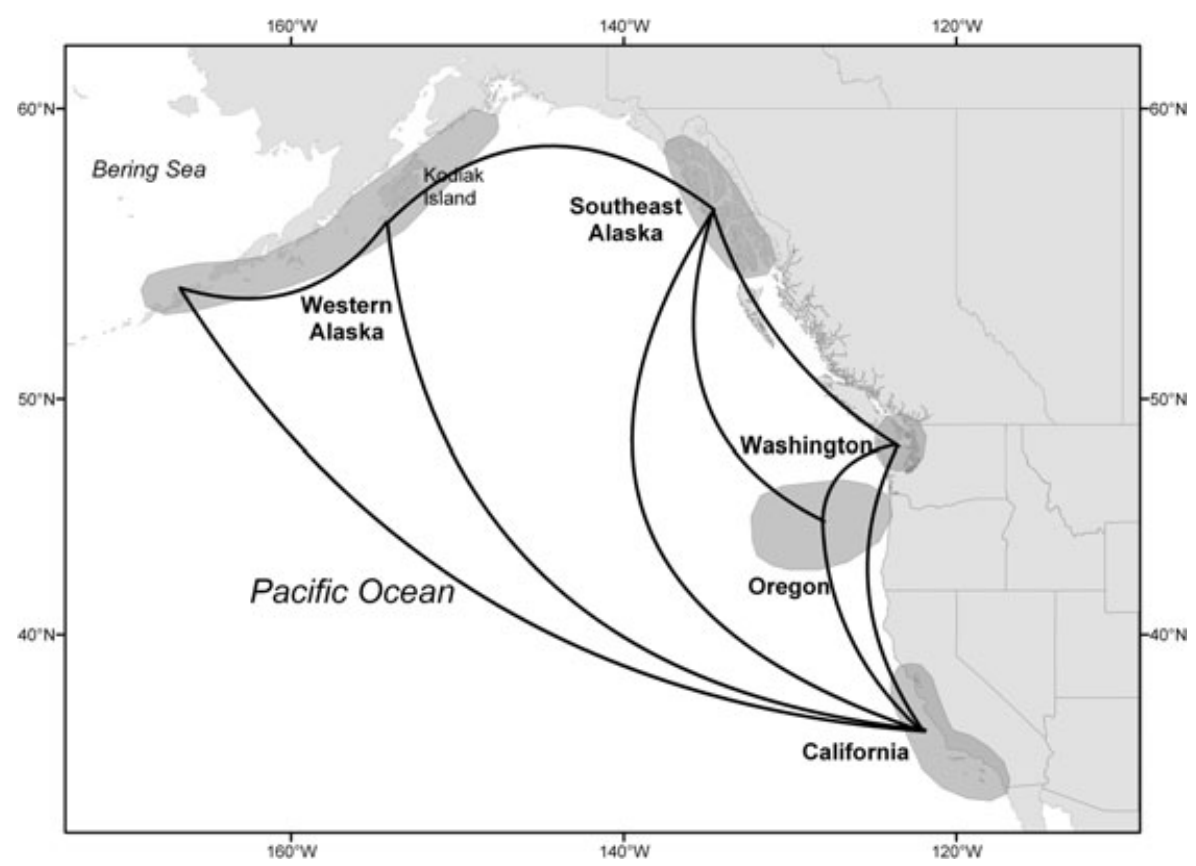

Figure 3. Large-scale movements of offshore killer whales among study areas based on photographic matches. Lines do not indicate actual movements.

Point, California. Another long-distance movement of 4,345 km occurred between Dutch Harbor, Alaska and Los Angeles, California. Whales were documented to travel between Kodiak Island, Alaska to Los Angeles, California $(3,723 \mathrm{~km})$ and between Kodiak Island and Monterey, California $(3,267 \mathrm{~km})$. Other long-range movements included travels between Southeast Alaska and Los Angeles $(2,756 \mathrm{~km})$ and Southeast Alaska and Monterey, California $(2,346 \mathrm{~km})$. Some whales were observed to make these long-distance movements within the same year. Resightings in the same

Table 1. Number of distinctive offshore killer whales identified by study area and photographic matches among locations.

\begin{tabular}{|c|c|c|c|c|c|c|c|c|}
\hline Location & & 1 & 2 & 3 & 4 & 5 & 6 & 7 \\
\hline $\begin{array}{l}\text { No. of distinct offshore killer } \\
\text { whales identified }\end{array}$ & & 69 & 157 & 9 & 118 & 96 & 26 & 53 \\
\hline Southern California & 1 & & & & & & & \\
\hline Central California & 2 & 51 & & & & & & \\
\hline Oregon & 3 & 2 & 3 & & & & & \\
\hline Washington & 4 & 51 & 61 & 2 & & & & \\
\hline Southeast Alaska & 5 & 36 & 48 & 3 & 45 & & & \\
\hline Gulf of Alaska & 6 & 4 & 14 & 0 & 0 & 6 & & \\
\hline Bering Sea & 7 & 5 & 22 & 0 & 17 & 9 & 6 & \\
\hline
\end{tabular}


year of an individual or group of offshore whales also allowed us to estimate the maximum travel time between locations. Two whales moved from Kodiak, Alaska (26 July 2001) to Monterey, California (11 October 2001) in just $77 \mathrm{~d}$; a distance of 3,267 km. Another whale identified in Monterey, California (28 February 1999) was resighted in the Queen Charlotte Islands, British Columbia (matched to the photo-identification catalogue; see Ford et al. 1992) 78 days later; a distance of $2,122 \mathrm{~km}$. Assuming the whales departed and arrived on the actual dates reported, the southbound pair of whales would have traveled an average of $42.4 \mathrm{~km}$ per day whereas the northbound whale averaged $27.2 \mathrm{~km}$ per day.

Offshore killer whales were shown to move a one-way distance of at least $4,435 \mathrm{~km}$; a value far exceeding that reported for other killer whale eco-types. Southern resident killer whales have been documented both in Monterey Bay, California and off Langara Island, British Columbia $(2,129 \mathrm{~km})$; however, these two encounters did not occur in the same year (N.B., personal observation; Ford ${ }^{1}$ ). Goley and Straley (1994) documented a movement of 2,660 km by three transient killer whales between Southeast Alaska (August 1989) to Monterey, California (May 1992). A single, male killer whale was photographically matched between Mexico (1988) and Peru (2001), a distance of 5,535 km (Guerrero-Ruiz et al. 2005). However, due to poor photographic quality, this report must be viewed with caution. Although offshore killer whales have been encountered far less frequently than resident and transient killer whales, the greater number of photographic matches made among widely spaced geographical regions suggest that offshore killer whales occupy a much larger range than that described for resident and transient killer whales.

Detailed behavioral notes were taken during each encounter. In Alaska, on three occasions whales were seen close to shore and were continually diving over the same area. During another encounter, offshore whales were first observed milling near shore. Eventually, the whales spread across a larger area into groups of three or four individuals. On two other occasions, whales were seen rapidly swimming at the surface as birds hovered overhead and picked up small bits of prey remains. In Washington, offshore whales appeared to be surface feeding on two occasions. In all cases, target prey could not be identified.

Off central California, offshore whales were also seen to form smaller subgroups and then spread out over greater distances during what we believed to be a foraging event. On two occasions in Monterey Bay, some offshore killer whales were observed with Chinook salmon (Onchorynchus tshawytscha) in their mouths. Similar to Alaska observations, birds were seen diving in the vicinity of the whales picking up bits and pieces of floating material consistent with salmon remains. On another occasion, several offshore whales were observed tail slapping blue sharks (Prionace glauca) and then dragging these sharks underwater. Unfortunately for both of these accounts, we could not verify actual consumption. Off southern California, offshore whales were seen on at least six occasions to mill, tail slap, and then dive repeatedly into schooling fish and squid, accompanied by circling birds. During these events, large groups of

\footnotetext{
1 Personal communication from John Ford, Fisheries and Oceans Canada, Pacific Biological Station, Nanaimo, BC V9T 6N7, Canada, 19 October 2007.
} 
offshore whales broke up into smaller subgroups and then spread out over large areas. On several occasions in California, offshore killer whales were observed in close proximity to sea lions (Zalophus californianus), gray whales (Eschrichtius robustus), fin whales (Balaenoptera physalus), and common dolphins (Delphinus delphis). No evidence of predation was noted and in no cases did these species behave as if they considered the offshore killer whales to be a predatory threat. In fact, during another encounter, Risso's dolphins (Grampus griseus) were seen harassing a pair of offshore killer whales; the dolphins appeared to drive off the female offshore killer whale while closely flanking her male companion.

Based upon our collective observations of feeding events made during this study, we believe that fish are the primary prey of offshore killer whales. Several independent sources corroborate our findings. Ford et al. (1992) reported salmon consumption by offshore killer whales in the Queen Charlotte Islands. An inspection of the stomach contents of two stranded offshore killer whales noted both salmon bones (Oncorbynchus sp.) and sculpin (Cottus sp.) (Heise et al. 2003). Jones (2006) observed offshore killer whales eating Pacific halibut (Hippoglossus stenolepis). Stomach contents of a stranded killer whale collected on 9 January 1964 off the central California coast $\left(33^{\circ} 50^{\prime} \mathrm{N}, 120^{\circ} 31^{\prime} \mathrm{W}\right)$, confirmed through genetic analysis as an offshore haplotype (Morin et al. 2006), contained six pectoral flippers belonging to three unidentified sharks, two large teleost fish skulls, and two fish identified as Opah (Lampris guttatu). Pectoral and pelvic fins of a carcharinid shark were also noted.

A fish diet is also consistent with group size and feeding behaviors. Offshore killer whales were frequently found in large groups similar to those reported for resident killer whales (Ford et al. 2000). During foraging events, we have observed large aggregations of offshore killer whales split into smaller groups and spread out across a large area, a behavior similar to resident killer whales that are foraging on salmon (Ford et al. 2000). Acoustic signaling (i.e., both communication and echolocation) is frequently heard when offshore killer whale groups are widespread; again similar to the acoustic behavior described for foraging resident killer whales. Conversely, transient killer whales typically hunt in small groups and remain silent, presumably to remain undetected by their prey. Using stable isotope ratios of carbon and nitrogen and fatty acid profiles to assess the dietary preferences of eastern North Pacific killer whales, Krahn et al. (2007) suggested that offshore killer whales were consuming prey species distinctly different from those of sympatric resident and transient whales. Offshore killer whales were shown to contain high levels of PCB and DDT, indicating that they may consume longer-lived fish species (e.g., rockfish, shark, tuna) that bio-accumulate high levels of contaminants. These findings could also suggest consumption of marine mammals; however, based on field observations, we believe that this is unlikely. Alternatively, the high contaminant loads could result from the fact that offshore killer whales frequently occur in California waters adjacent to areas of high human density, agricultural regions, and other industrialized areas where runoff may occur.

Tooth wear has been linked to the type of prey consumed (Caldwell and Brown 1964). A Newport Beach (California) killer whale specimen, cited in Caldwell and 
Brown (1964), showed extreme tooth wear (i.e., teeth worn down to the gumline) as did the 9 January 1964 specimen described above. Both were subsequently identified as the offshore haplotype (Morin et al. 2006). Two offshore killer whales that died in Barnes Lake (Southeast Alaska) also had teeth worn down to the gumline (Bain 1995). The same pattern of extensive tooth wear was reported from a mass stranding of killer whales in the Gulf of California, Mexico (Guerrero-Ruiz et al. 2006). Our photographic data also provided some interesting patterns related to offshore killer whale dentition. Resident and transient whales typically showed extensive rake marks on their dorsal fins and body made by the conical-shaped teeth of conspecifics (Ford et al. 1992, Black et al. 1997, Dahlheim et al. 1997). During our analyses of photographic data on offshore killer whales, we did not observe extensive rake markings. We did, however, see wider and shallower markings on the skin of offshore killer whales, the width of which was consistent with rake marks inflicted by teeth that had extensive wear. The causes responsible for the extreme tooth wear seen in offshore killer whales is unknown but is undoubtedly related to the type of prey being consumed. If this condition were caused by crushing bones (e.g., predating on other marine mammals), we would expect transient killer whale teeth to exhibit this condition. An examination of several North Pacific transient killer whale skulls containing teeth, available for inspection at various museums, did not find extensive tooth wear as that described above for offshore killer whales (NMML, unpublished data).

Based on the increase in the number of encounters with offshore killer whales since 1992, one could assume that their presence in our inland and coastal waters is a fairly recent event. An inspection of the killer whale stranding data along the west coast of North America provides some interesting insights. In 1941, 11 killer whales (four males, seven females) were stranded near Masset on the Queen Charlotte Islands in British Columbia Canada (Cameron 1941). The largest male was $20 \mathrm{ft}, 5$ in. $(6.2 \mathrm{~m})$, and the largest female was $18 \mathrm{ft}, 7$ in. (5.7 m) Carl (1946), reporting on a killer whale stranding at Estevan Point (Vancouver Island, British Columbia, Canada), noted an average length for four adult males at $21 \mathrm{ft}, 4$ in. $(6.5 \mathrm{~m})$, and 12 adult females at $18 \mathrm{ft}(5.5 \mathrm{~m})$. In both strandings, the maximum whale lengths reported are considerably shorter than the lengths documented for resident and transient killer whales (Dahlheim and Heyning 1999; NMML, unpublished data). Carl (1946) also stated that sexual disparity in size was not nearly as great as expected when compared to previously published accounts. Likewise, we observed that offshore killer whales appear smaller than residents or transients, with less sexual dimorphism in length. Although genetic studies are warranted, both the overall length measurements reported for the whales in the two Canadian strandings and the extreme tooth wear reported by Carl (1946) suggest that these whales may have been the offshore killer whale ecotype. This would document the presence of this ecotype off the Canadian coast at least 65 years ago. Genetic examination of historical bone and tooth samples from California found eight whales described as the offshore haplotype (Morin et al. (2006); one specimen dated back to the 1800s, while several others were collected during the 1950s and 1960s. If we assume that haplotype implies ecotype, a pattern believed to be true for eastern temperate North Pacific 
killer whales, and that stranding data represents movements of healthy animals, then these genetic data imply that offshore killer whales were coastal visitors off California nearly 50 years ago or possibly as long as 100 years ago.

In conclusion, it is currently unclear as to whether offshore killer whales in the eastern temperature North Pacific are truly an open-ocean population or a continental shelf population. For this reason, the term "offshore" killer whale is meant only as a population identifier. Offshore killer whales were shown to travel extensively throughout their range. Their presence in coastal and inland waters remains sporadic with occurrence undoubtedly tied to prey availability; which we believe are fish. When compared to resident and transient killer whales, offshore killer whales have been shown to differ in morphology, behavior, and genetics. This study lends further support to the recognition that eastern temperate North Pacific offshore killer whales should be managed as a third killer whale eco-type.

\section{ACKNOWLEDGMENTS}

We thank the captains and crew aboard the Alaskan vessels NOAA R/V Jobn N. Cobb, F/V Aleutian Mariner, R/V Alpha Helix, and the F/V Coastal Pilot. We also thank the numerous observers and photographers that assisted us throughout the years both in Alaska data collection and analysis. For the western Alaska studies, we thank the photographic and genetic contributions of John Durban, Bob Pitman, and Paul Wade. Candi Emmons participated in several Southeast Alaska cruises and assisted at various stages with the analysis of the Alaskan data. Captains Jim Collins and Lennie Gorsuch (Allen Marine Tours, Juneau, Alaska) and Mark Kelley provided photographic data from the April 2006 sighting in Southeast Alaska. For Washington, we thank the following photographers: Robin Baird, Dianne Claridge, Astrid van Ginneken, and Candi Emmons. Graeme Ellis assisted in the analysis of photographic data from this region. We thank Jay Barlow and Karin Forney for sighting data collected off Oregon. For California it is not possible to list the many people who comprise the extensive sighting network in this area; their help is greatly appreciated and we thank them all. The co-operation of the sport, recreational, and commercial fishermen is invaluable to our research. Off central California, we thank the captains and crews aboard the R/V Jobn H. Martin, Pt. Lobos, Pt. Sur, and the Western Flyer. We would also like to thank the entire whale watching community in Monterey Bay, California. Off southern California, we especially thank Eric Martin and the ACS/LA Gray Whale Census and Behavior Project volunteer observers. We are also indebted to David Janiger for his numerous contributions to this project; his assistance was extremely valuable. Dana Drake (Panda Laboratories, Inc.) developed and produced the high-quality photographs of Alaskan killer whales for this project. Janice Waite (AFSC, NMML) produced the figures. We thank Paula White, Janice Waite, Bob Dahlheim, Jeff Laake, Robin Baird, and Phil Clapham for their helpful comments on this manuscript.

\section{Literature Cited}

BAIN, D. E. 1995. The use of sound to guide killer whales (Orcinus orca) entrapped in Barnes Lake, Alaska, to open water. Abstract presented at the Eleventh Biennial Conference on the Biology of Marine Mammals, 14-18 December 1995 Orlando, FL. p. 6.

BAIRD, R. W., AND P. J. STACEY. 1988. Variation in saddle patch pigmentation in populations of killer whales (Orcinus orca) from British Columbia, Alaska, and Washington State. Canadian Journal of Zoology 66:2582-2585. 
Black, N. A., A. Schulman-Janiger, R. L. Ternullo and M. Guerrero-Ruiz. 1997. Killer whales of California and western Mexico: A catalogue of photo-identified Individuals. U. S. Department of Commerce. NOAA Technical Memorandum SWFSC 247. $174 \mathrm{pp}$.

Caldwell, D. K, AND D. H. Brown. 1964. Tooth wear as a correlate of described feeding behavior by the killer whale, with notes on a captive specimen. Bulletin of the Southern California Academy of Sciences 63:128-140.

Cameron, W. M. 1941. Killer whales stranded near Masset. Progress report of the Pacific Biological Station, Nanaimo, B. C. and Pacific Fisheries Experimental Station, Prince Rupert, British Columbia 49:17.

CARL, G. C. 1946. A school of killer whales stranded at Estevan Point, Vancouver Island. Report for the Provincial Museum of Natural History and Anthropology 1945:B21B28.

Dahlheim, M. E., And J. E. Heyning. 1999. Killer whale Orcinus orca (Linnaeus, 1758). Pages 281-322 in S. H. Ridgway and R. Harrison, eds. Handbook of marine mammals, Volume 6. Academic Press, San Diego, CA.

Dahlheim, M. E., D. K. Ellifrit and J. D. Swenson. 1997. Killer whales of southeast Alaska: A catalogue of photo-identified individuals. Day Moon Press, Seattle, WA.

Ford, J. K. B., G. M. Ellis AND L. M. Nichol. 1992. Killer whales of the Queen Charlotte Islands: A preliminary study of the abundance, distribution, and population identity of Orcinus orca in the waters of Haida Gwaii. Prepared for South Moresby/Gwaii Haana National Park Reserve, Canadian Park Service, Queen Charlotte City, British Columbia, Canada. 69 pp.

Ford, J. K. B., G. M Ellis AND K. C. BALCOMB. 2000. Killer whales: The natural history and genealogy of Orcinus orca in British Columbia and Washington. UBC Press, Vancouver, $\mathrm{BC}$ and University of Washington Press, Seattle, WA.

Goley, P. D., AND J. M. STRAley. 1994. Attack on gray whales (Eschrichtius robustus) in Monterey Bay, California, by killer whales (Orcinus orca) previously identified in Glacier Bay, Alaska. Canadian Journal of Zoology 72:1528-1530.

Guerrero-Ruiz, M., I. Garcia-Godos and J. Urban R. 2005. Photographic match of a killer whale (Orcinus orca) between Peruvian and Mexican waters. Aquatic Mammals 31:438-441.

Guerrero-Ruiz, M., H. Perez-Cortes, M. Salinas and J. Urban. 2006. First mass stranding of killer whales (Orcinus orca) in the Gulf of California, Mexico. Aquatic Mammals 32:265-272.

Heise, K., L. Barrett-Lennard, J. K. B. Ford and G. Ellis. 1993. Killer whales of the Queen Charlotte Islands. Prepared for the South Moresby/Gwaii Haanas National Park Reserve, Canadian Park Service, Queen Charlotte City, British Columbia. 36 pp.

Heise, K., L. Barrett-Lennard, E. Saulitis, C. Matkin and D. Bain. 2003. Examining the evidence for killer whale predation on Stellar sea lions in British Columbia and Alaska. Aquatic Mammals 29:325-334.

Hoelzel, A. R., M. E. Dahlheim And S. J. Stern. 1998. Low genetic variation among killer whales (Orcinus orca) in the eastern North Pacific, and genetic differentiation between foraging specialists. Journal of Heredity 89:121-128.

Hoelzel, A. R., A. Natoli, M. E. Dahlheim, C. Olavarria, R. W. Baird and N. A. Black. 2002. Low worldwide genetic diversity in the killer whale (Orcinus orca): Implications for demographic history. Proceedings of the Royal Society of London, Series B 269:14671473.

JonEs, I. M. 2006. A Northeast Pacific offshore killer whale (Orcinus orca) feeding on a Pacific halibut (Hippoglossus stenolepis). Marine Mammal Science 22:198-200.

Krahn, M. M., D. P. Herman, C. O. Matkin, J. W. Durban, L. Barrett-Lennard, D. G. Burrows, M. E. Dahlheim, N. Black, R. G. LeDuc and P. R. Wade. 2007. Use of chemical tracers in assessing the diet and foraging regions of eastern North Pacific killer whales. Marine Environmental Research 63:91-114. 
Morin, P. A., R. G. LeDuc, K. M. Robertson, N. M. Hedrick, W. F. Perrin, M. Etnier, P. WADE AND B. L. TAYLOR. 2006. Genetic analysis of killer whale (Orcinus orca) historical bone and tooth samples to identify western U.S. ecotypes. Marine Mammal Science 22:897-909.

Walters, E. L., R. W. Baird and T. J. Guenther. 1992. New killer whale "pod" discovered near Victoria. Victoria Naturalist. 49:7.

Received: 13 February 2007

Accepted: 26 February 2008 